\title{
INFLUENCE OF DOSE AND USP DISSOLUTION APPARATUS IN THE RELEASE PERFORMANCE OF REFERENCE TABLETS: PROPRANOLOL-HCl AND RANITIDINE-HCI CASES
}

\author{
JOSE RAUL MEDINA-LOPEZ , LUIS ANTONIO CEDILLO-DIAZ, MARCELA HURTADO
}

Departamento Sistemas Biológicos, Universidad Autónoma Metropolitana-Xochimilco, Mexico DF, Mexico

Email: rmlopez@correo.xoc.uam.mx

Received: 31 Mar 2019, Revised and Accepted: 10 May 2019

\begin{abstract}
Objective: Due to quality of generic formulations depends on available information of reference drug products the aim of this work was to perform an in vitro dissolution study of two doses of propranolol- $\mathrm{HCl}$ and ranitidine-HCl reference tablets using USP basket or paddle apparatus and flowthrough cell method.

Methods: Two doses of propranolol-HCl (10-mg and 80-mg) and ranitidine-HCl (150-mg and 300-mg) of Mexican reference products were used. Dissolution profiles of propranolol-HCl were obtained with USP basket apparatus at $100 \mathrm{rpm}$ and $1000 \mathrm{ml}$ of $1 \%$ hydrochloric acid. Profiles of ranitidine-HCl were determined with USP paddle apparatus at $50 \mathrm{rpm}$ and $900 \mathrm{ml}$ of distilled water. All formulations were also studied with the flow-through cell method using laminar flow at $16 \mathrm{ml} / \mathrm{min}$. Dissolution profiles were compared by model-independent $\left(f_{2}\right.$ similarity factor, mean dissolution time and dissolution efficiency) and model-dependent methods (dissolution data adjusted to some mathematical equations). Time data, derived from these adjustments, as $\mathrm{t}_{50 \%}, \mathrm{t}_{63.25 \%}$, and $\mathrm{t}_{85 \%}$ were used to compare dissolution profiles.
\end{abstract}

Results: With all approaches used and being high solubility drugs significant differences were found between low and high doses and between USP dissolution apparatuses $(* \mathrm{P}<0.05)$.

Conclusion: In vitro dissolution performance of two doses of propranolol-HCl and ranitidine- $\mathrm{HCl}$ was not expected. Considering the same USP dissolution apparatus, the reference tablets did not allow the simultaneous release of the used doses. The results could be of interest for pharmaceutical laboratories or health authorities that classify some drug products as a reference to be used in dissolution and bioequivalence studies.

Keywords: Flow-through cell method, Propranolol-HCl tablets, Ranitidine-HCl tablets, Reference drug products, USP basket apparatus, USP paddle apparatus

(C) 2019 The Authors. Published by Innovare Academic Sciences Pvt Ltd. This is an open-access article under the CC BY license (http://creativecommons.org/licenses/by/4.0/) DOI: http://dx.doi.org/10.22159/ijap.2019v11i4.33293

\section{INTRODUCTION}

Propranolol is a non-selective $\beta$-adrenergic receptor-blocking agent. It is used to treat high blood pressure (hypertension) and severe infantile hemangioma [1]. Due to propranolol short biological halflife (3-5 h), it needs to be administered in two or three doses of 40 to $80 \mathrm{mg}$ per day [2]. Ranitidine- $\mathrm{HCl}$ is a $\mathrm{H}_{2}$ receptor antagonist used in the treatment of gastric and duodenal ulceration and gastrooesophageal reflux disease. It is absorbed from the gastrointestinal tract with the bioavailability of about $50 \%$ and an elimination halflife of $3 \mathrm{~h}$ [3]. Chemical structures of used drugs are shown in fig. 1.

A<smiles>CC(C)NCC(O)COc1cccc2ccccc12</smiles>

B

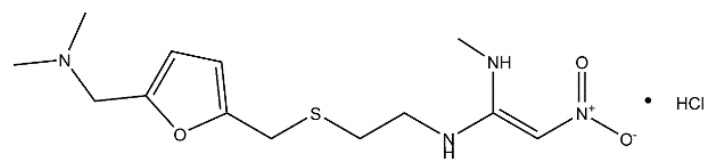

Fig. 1: Chemical structures of propranolol-HCl (A) and ranitidine-HCl (B)

Propranolol- $\mathrm{HCl}$ and ranitidine- $\mathrm{HCl}$ are included in the WHO Model List of Essential Medicines [4], and because of its wide use, these drugs are manufactured as generic formulations. This kind of formulations offer savings for patients, hospitals and pharmaceutical laboratories. Generic formulations should be evaluated periodically to ensure a similar therapeutic effect to that of the reference, so quality of generic formulations depends on the quality of reference drug products. In vitro dissolution studies are important to know the dissolution performance of reference products considering factors as dose and hydrodynamics.

According to the Biopharmaceutics Classification System (BCS) propranolol is a class I drug (high solubility/high permeability) [5]. Solubility of propranolol-HCl in water is reported as $1 \mathrm{~g}$ in $10-30 \mathrm{ml}$ [6]. Ranitidine-HCl is a class III drug (high solubility/low permeability). Solubility of ranitidine- $\mathrm{HCl}$ in water is $660 \mathrm{mg} / \mathrm{ml}$ [7]. For propranolol$\mathrm{HCl}$, solubility within the physiological $\mathrm{pH}$ is not critical, so the dissolution rate of the formulation will be the decisive factor for its bioavailability [6]. For class I drugs, the dissolution of more than $85 \%$ at 30 min makes the comparison of dissolution profiles between reference and test (generic) formulation unnecessary [8]

Official dissolution tests for propranolol-HCl and ranitidine- $\mathrm{HCl}$ tablets are described in United States Pharmacopoeia (USP) [9] and Mexican Pharmacopoeia [10]. Dissolution conditions for propranolol-HCl include USP basket apparatus (USP Apparatus 1) at $100 \mathrm{rpm}$ and $1000 \mathrm{ml}$ of $1 \%$ hydrochloric acid at $37.0 \pm 0.5{ }^{\circ} \mathrm{C}$ as dissolution medium. Under these conditions, not less than $75 \%$ of drug should be dissolved in $30 \mathrm{~min}(\mathrm{Q} \geq$ 75\%). Dissolution conditions for ranitidine-HCl include USP paddle apparatus (USP Apparatus 2) at 50 and $900 \mathrm{ml}$ of distilled water at $37.0 \pm 0.5^{\circ} \mathrm{C}$. Not less than $80 \%$ should be dissolved at $45 \mathrm{~min}(\mathrm{Q} \geq 80 \%)$. Biowaiver monographs for propranolol- $\mathrm{HCl}$ [6] and ranitidine- $\mathrm{HCl}$ [7] have been published suggesting the replacing of in vivo studies for in vitro dissolution studies.

Additional dissolution tests to those established with USP vessels apparatus (USP Apparatus 1 or 2) have been developed with flowthrough cell method (USP Apparatus 4). Its advantages over conventional USP basket and paddle apparatuses have been widely demonstrated, especially with dissolution of poorly soluble drugs 
$[11,12]$. The flow-through cell method has a continuous extraction of the drug, simulating the absorption into the systemic circulation, by generating intermittent flow of dissolution medium inside the compartment where the dosage form is placed [13]. The USP Apparatus 4 better simulates the hydrodynamic environment found in the gastrointestinal tract. Previous reports show that in vitro data obtained with flow-through cell method better reflect in vivo performance of some drugs $[14,15]$. Despite the advantages of USP Apparatus 4, information about dissolution performance of propranolol- $\mathrm{HCl}$ and ranitidine- $\mathrm{HCl}$ reference tablets is scarce.

A comparative dissolution study of metronidazole with reference and generic formulations has been published [16]. In the study, two doses of metronidazole tablets and two USP dissolution apparatuses were used and significant differences in dissolution profiles of metronidazole from reference formulation were found. For this antimicrobial drug a biowaiver monograph has also been published [17]. For its high solubility and dissolution conditions used no problem should present the in vitro dissolution of both metronidazole doses however, its dissolution performance was not as expected. Daousani and Macheras [18], based on a previous analysis of theoretical and experimental data, established the drug dose as an important parameter for drug dissolution and biopharmaceutic drug classification.

The main objective of this in vitro release study was to evaluate the dissolution performance of propranolol-HCl and ranitidine- $\mathrm{HCl}$ reference tablets using two doses of each drug and two dissolution apparatuses. The results could be of interest for pharmaceutical laboratories or health authorities that classify some drug products as a reference to be used in dissolution and bioequivalence studies.

\section{MATERIALS AND METHODS}

\section{Materials}

Propranolol-HCl (Inderalici ${ }^{\circledR}, 10-\mathrm{mg}$ and 80-mg, AstraZeneca SA de CV) and ranitidine-HCl (Azantac $®, 150-\mathrm{mg}$ and 300-mg, Grimann SA de CV) tablets were used. Mexican health regulatory agency COFEPRIS has established both drug products as a reference to be used in bioequivalence studies [19]. Hydrochloric acid and methanol analytical grade were purchased from J. T. Baker-Mexico. Propranolol-HCl and ranitidine-HCl standard were purchased from Sigma-Aldrich Co. (St. Louis MO, USA).

\section{Content uniformity and assay}

Content uniformity and assay tests with all reference formulations were performed according to the procedures described in US Pharmacopeia [9].

\section{Dissolution profiles}

\section{USP vessels apparatus}

Dissolution profiles of propranolol- $\mathrm{HCl}$ and ranitidine- $\mathrm{HCl}$ were determined according to USP tests [9] using an automated USP vessels apparatus (Sotax AT-7 Smart, Switzerland) with a piston pump (Sotax CY7-50, Switzerland). An UV/Vis spectrophotometer with 1-mm flow cells (Perkin Elmer Lambda 35, USA) was used. All equipment and data generated were controlled by specific software designed by Sotax. Dissolution profiles of propranolol-HCl tablets were determined with USP Apparatus 1 at $100 \mathrm{rpm}$. Tablets were sprinkled on $1000 \mathrm{ml}$ of $1 \%$ hydrochloric acid. Dissolution profiles of ranitidine- $\mathrm{HCl}$ were obtained with USP Apparatus 2 at $50 \mathrm{rpm}$. Tablets were sprinkled on $900 \mathrm{ml}$ of distilled water. Temperature of dissolution media was $37.0 \pm 0.5^{\circ} \mathrm{C}$. Sequential sampling using 0.45 $\mu \mathrm{m}$ nitrocellulose filters (Millipore $囚$ ) occurred over $30 \mathrm{~min}$ (propranolol-HCl) or $45 \mathrm{~min}$ (ranitidine- $\mathrm{HCl}$ ) at regular 5-min intervals with 12 replicates. The amount of propranolol- $\mathrm{HCl}$ and ranitidine- $\mathrm{HCl}$ dissolved was determined with standard calibration curves at 289 and $314 \mathrm{~nm}$, respectively.

\section{Flow-through cell method}

Dissolution profiles of propranolol- $\mathrm{HCl}$ and ranitidine- $\mathrm{HCl}$ were obtained in an automated USP Apparatus 4 (Sotax CE6, Sotax AG, Switzerland) with 22.6-mm cells (i.d.) and a piston pump (Sotax CY750, Sotax AG, Switzerland). Laminar flow (with a bed of $6 \mathrm{~g}$ of glass beads) was used. The degassed dissolution media at $37.0 \pm 0.5{ }^{\circ} \mathrm{C}, 1 \%$ hydrochloric acid and distilled water, were pumped at $16 \mathrm{ml} / \mathrm{min}$. An open system was used without recycling the dissolution media. Sequential sampling using nitrocellulose filters was set at regular 5min intervals over 30 or $45 \mathrm{~min}$, with 12 replicates. The amount of propranolol- $\mathrm{HCl}$ and ranitidine- $\mathrm{HCl}$ dissolved was determined in a UV/Vis spectrophotometer with 1-mm cells (Perkin Elmer Lambda 10, USA) at 289 and $314 \mathrm{~nm}$, respectively. For every trial, a standard calibration curve was prepared.

\section{Dissolution data analysis}

Dissolution profiles of propranolol-HCl and ranitidine- $\mathrm{HCl}$ were compared by model-independent and model-dependent approaches. For the first kind of comparison, $f_{2}$ similarity factor was calculated according to equation 1 [20]:

$$
\mathrm{f}_{2}=50 \times \log \left\{\left[1+\left(\frac{1}{n}\right) \sum_{\mathrm{j}=1}^{\mathrm{n}}\left|\mathrm{R}_{\mathrm{j}}-\mathrm{T}_{\mathrm{j}}\right|^{2}\right]^{-0.5}\right\} \times 100 \text { Eq. [1] }
$$

Where $\mathrm{n}$ is the number of time points used to evaluate the amount of drug dissolved, $\mathrm{Rj}$ and $\mathrm{Tj}$ are the average percentages of drug dissolved at a j specific time from reference and test products, respectively.

Similar dissolution profiles were found when $f_{2}=50-100$ [20]. Then, dissolution profiles were compared with the following modelindependent parameters: percentage of drug dissolved at last sampling time ( $Q$ criterion), mean dissolution time (MDT) and dissolution efficiency (DE). $Q$ value is a quality pharmacopeial criterion used to compare the extent of drug dissolved (batch-tobatch or after some modifications of the manufacturing process) [9]. MDT is the time necessary to dissolve $63.2 \%$ of drug and it is calculated with statistical moment's theory [21]. DE is the area under the dissolution curve up to a certain time, $t$, expressed as a percentage of the area of the rectangle described by $100 \%$ dissolution over the same time [22]. MDT and DE are commonly used parameters to IVIVC level B and C, respectively [23].

For model-dependent comparisons, dissolution data of propranolol$\mathrm{HCl}$ and ranitidine- $\mathrm{HCl}$ formulations were fitted to Hyperbole, Higuchi, Korsmeyer-Peppas, Hixson-Crowell, Makoid-Banakar, Weibull, Logistic, and Gompertz model. Mathematical equations of all models (excepting Hyperbole model) were described by Zhang $e t$ al. [24] and are shown in table 1.

Table 1: Mathematical equations used to fit dissolution data

\begin{tabular}{llll}
\hline Model & Equation & Model & Equation \\
\hline Hyperbole & $\begin{array}{l}y=\frac{a x}{b+x} \\
F=k_{H} \cdot t^{0.5}\end{array}$ & Makoid-Banakar & $F=k_{M B} \cdot t^{n} \cdot e^{-k t}$ \\
Higuchi & Weibull & & $F=F_{\max } \cdot\left[1-e^{-\frac{\left(t-t_{i}\right)^{\beta}}{\alpha}}\right]$ \\
Korsmeyer-Peppas & $F=k_{K P} \cdot t^{n}$ & Logistic & $F=100 \cdot \frac{e^{\alpha-\beta \cdot \log (t)}}{1-e^{\alpha+\beta \cdot \log (t)}}$ \\
Hixson-Crowell & $F=100\left[1-\left(1-k_{H C} \cdot t\right)^{3}\right]$ & Gompertz & $F=100 \cdot e^{-\alpha \cdot e^{-\beta \cdot \log (t)}}$ \\
\hline
\end{tabular}

Dissolution data were adjusted to hyperbole equation with SigmaPlot software (version 11.0 ) and $t_{50 \%}, t_{63.2 \%}$, and $t_{85 \%}$ values were calculated after adjustment to this mathematical equation. For the rest of the adjustments, the model with the highest determination coefficient $\left(\mathrm{R}^{2}\right.$ adjusted) and the minimum Akaike Information Criterion (AIC) was chosen as the best fit model [25]. $f_{2}$, MDT, DE, and adjustment to all 
models (excepting hyperbole) was calculated with Excel add-in DDSolver program [24]. Mean values were compared by a Student's $t$ test and significant differences were considered if $* \mathrm{P}<0.05$.

\section{RESULTS AND DISCUSSION}

\section{Content uniformity and assay}

All formulations were within USP limits. The percentages of propranolol- $\mathrm{HCl}$ and ranitidine- $\mathrm{HCl}$ on the content uniformity tests ranged from $85-115 \%$ and the assay tests between $90-110 \%$. Results are shown in table 2.

\section{Dissolution profiles}

\section{Model-independent comparisons}

Dissolution profiles of propranolol-HCl and ranitidine- $\mathrm{HCl}$ from reference formulations, obtained with USP basket or paddle apparatus and flow-through cell method, are shown in fig. 2 .

Table 2: Content uniformity and assay results, $n=10 *$; mean $\pm \mathrm{SD}, n=3 \dagger$

\begin{tabular}{llll}
\hline Drug & Dose & Content uniformity (min-max\%)* & Assay (\%) $\dagger$ \\
\hline $\mathrm{P}$ & Low & $95.27-110.68$ & $106.34 \pm 1.72$ \\
& High & $101.15-108.45$ & $97.78 \pm 1.86$ \\
$\mathrm{R}$ & Low & $101.96-107.95$ & $101.84 \pm 4.65$ \\
& High & $101.72-109.07$ & $108.00 \pm 7.50$ \\
\hline
\end{tabular}

USP vessels apparatus
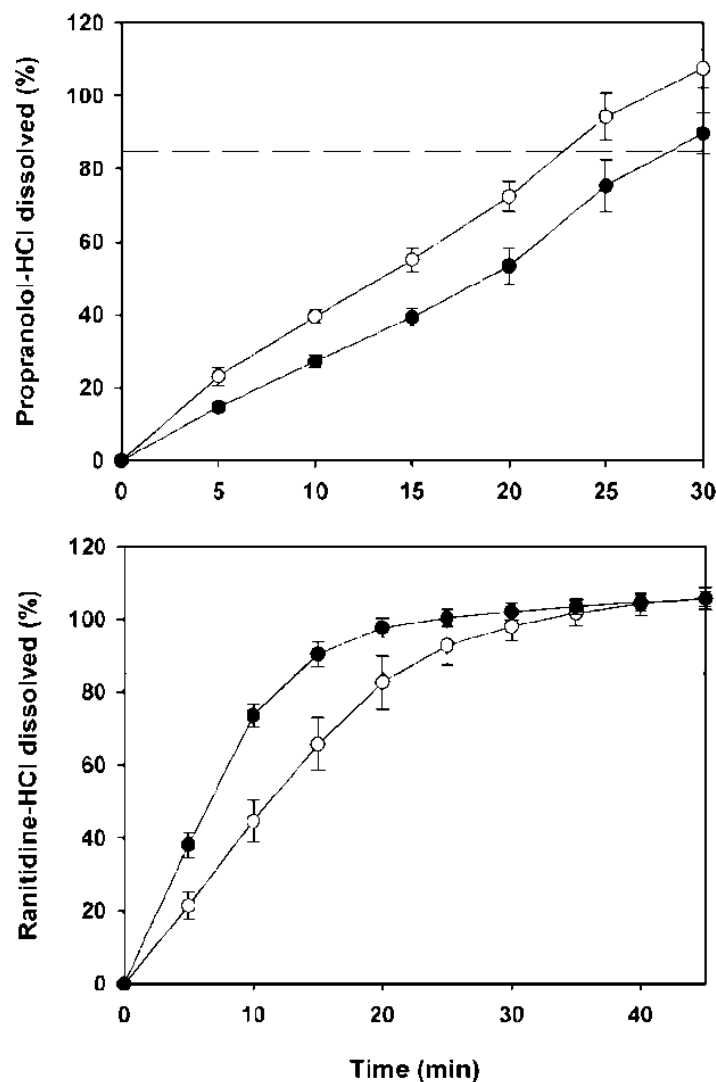

Flow-through cell method
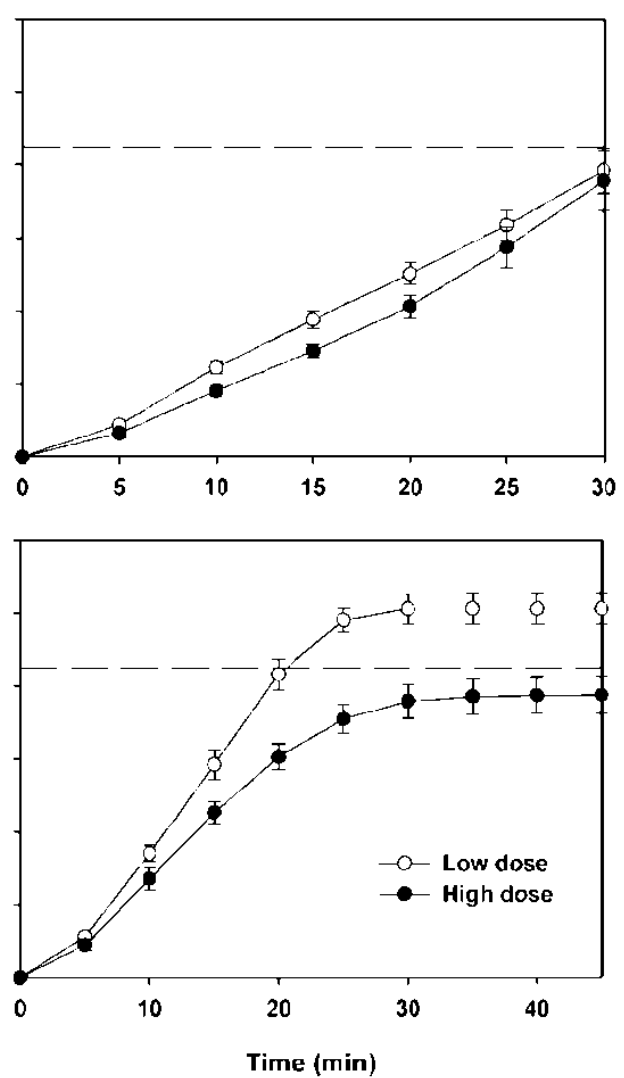

Fig. 2: Dissolution profiles of propranolol- $\mathrm{HCl}$ and ranitidine-HCl from reference formulations, the dotted line shows $85 \%$ of drug dissolved. mean $\pm S D, n=12$

Table 3: Model-independent and-dependent parameters of propranolol-HCl $(\mathrm{P})$ and ranitidine-HCl $(\mathrm{R}) . \mathrm{mean} \pm \mathrm{SEM}, \mathrm{n}=\mathbf{1 2}$. ${ }^{*} \mathrm{P}<0.05, \mathrm{Low}$ vs. High dose

\begin{tabular}{|c|c|c|c|c|c|c|}
\hline Drug/Dose & Diss. at last sampling time (\%) & MDT(min) & DE (\%) & $\mathbf{t}_{50 \%}$ (min) & $\mathrm{t}_{63.2 \%}$ (min) & $\mathrm{t}_{85 \%}$ (min) \\
\hline \multicolumn{7}{|c|}{ USP vessels apparatus } \\
\hline $\mathrm{P} / \mathrm{low}$ & $107.49 \pm 1.49$ & $14.27 \pm 0.15$ & $56.33 \pm 0.86$ & $13.08 \pm 0.23$ & $16.76 \pm 0.28$ & $23.08 \pm 0.35$ \\
\hline P/High & $89.68 \pm 1.64^{*}$ & $15.80 \pm 0.18^{*}$ & $42.42 \pm 0.76^{*}$ & $17.33 \pm 0.32 *$ & $21.94 \pm 0.41^{*}$ & $29.60 \pm 0.57^{*}$ \\
\hline R/low & $105.72 \pm 0.87$ & $13.60 \pm 0.37$ & $73.76 \pm 1.12$ & $10.17 \pm 0.45$ & $14.37 \pm 0.57$ & $24.04 \pm 0.77$ \\
\hline R/High & $105.57 \pm 0.64$ & $8.87 \pm 0.09 *$ & $84.77 \pm 0.57^{*}$ & $5.18 \pm 0.11^{*}$ & $7.84 \pm 0.17^{*}$ & $15.67 \pm 0.34^{*}$ \\
\hline \multicolumn{7}{|c|}{ Flow-through cell method } \\
\hline $\mathrm{P} /$ low & $78.41 \pm 1.77$ & $15.72 \pm 0.16$ & $37.27 \pm 0.64$ & $19.73 \pm 0.35$ & $24.91 \pm 0.45$ & $33.44 \pm 0.62$ \\
\hline P/High & $75.69 \pm 2.36$ & $17.39 \pm 0.23^{*}$ & $31.65 \pm 0.66^{*}$ & $22.12 \pm 0.58^{*}$ & $27.96 \pm 0.74^{*}$ & $37.61 \pm 0.99 *$ \\
\hline R/low & $101.20 \pm 1.20$ & $13.40 \pm 0.26$ & $71.00 \pm 0.53$ & $11.37 \pm 0.18$ & $15.84 \pm 0.21$ & $25.69 \pm 0.35$ \\
\hline R/High & $77.51 \pm 1.45^{*}$ & $13.93 \pm 0.16$ & $53.50 \pm 0.99 *$ & $17.30 \pm 0.58^{*}$ & $25.30 \pm 0.89 *$ & $46.09 \pm 1.94^{*}$ \\
\hline
\end{tabular}


All formulations met the pharmacopeial $Q$ criterion $(Q \geq 75 \%$ for propranolol-HCl and $Q \geq 80 \%$ for ranitidine-HCl), excepting high dose of ranitidine- $\mathrm{HCl}$ with flow-through cell apparatus $(Q=$ $77.51 \%)$. Specific data and comparison of drug dissolved at the last sampling time are shown in table 3.

It is important to highlight the lack of compliance of $Q$ criterion of a high dose of ranitidine-HCl with flow-through cell method. Dose, the total volume of dissolution medium and high solubility should be factors that favor ranitidine-HCl dissolution however, this does not happen. Something similar is observed with the dissolution of both drugs at 15 and $30 \mathrm{~min}$. A very rapid drug dissolution can be achieved if $\geq 85 \%$ drug is dissolved in $15 \mathrm{~min}$ [26] and rapid drug dissolution can be achieved if the same percentage of drug is reached in $30 \mathrm{~min}$ [27]. More than $85 \%$ of drug dissolved at $15 \mathrm{~min}$ is reached only by a high dose of ranitidine- $\mathrm{HCl}$ in USP paddle apparatus. More than $85 \%$ of drug dissolved at $30 \mathrm{~min}$ is reached by both doses of propranolol-HCl in USP basket apparatus, both doses of ranitidine-HCl in USP paddle apparatus and a low dose of ranitidine- $\mathrm{HCl}$ with flow-through cell method. Under dissolution conditions used, reference formulations should allow the complete release of both drugs, however, as previously mentioned, the high solubility of each drug and the volume of dissolution media are not enough factors to obtain the extent of dissolution that characterizes a drug product with very rapid or rapid dissolution.

As observed, with flow-through cell method the used formulations showed slower dissolution rates than that found with USP basket or paddle apparatus. Langenbucher et al. [28] stated that this kind of behavior can be explained by the hydrodynamic conditions generated by USP Apparatus 4, where there are no agitation mechanisms and the dosage form and drug particles are continuously exposed to a uniform laminar flow, similar to the natural environment of the gastrointestinal tract, causing a different dissolution pattern. With flow-through cell method, cell size, glass beads and flow rate are critical factors to form this special pattern. In this in vitro release study of propranolol- $\mathrm{HCl}$ and ranitidine- $\mathrm{HCl}$ flow rate of $16 \mathrm{ml} / \mathrm{min}$ was used because it is one of the three suggested by European and United States Pharmacopeias [29].

To compare dissolution profiles of low vs. high dose of propranolol$\mathrm{HCl}$ and ranitidine-HCl $f_{2}$ similarity factors were calculated. Additionally, USP vessels apparatus vs. flow-through cell method was also compared. Results are shown in table 4.

Table 4: $f_{2}$ similarity factor calculated to compare dissolution profiles of propranolol-HCl (P) and ranitidine-HCl (R) formulations

\begin{tabular}{llll}
\hline Comparison & Drug & Apparatus/Dose & $\boldsymbol{f}_{2}$ \\
\hline Low $v$ s. High & $\mathrm{P}$ & USP 1 & 41.58 \\
& & USP 4 & 61.12 \\
& $\mathrm{R}$ & USP 2 & 42.24 \\
& & USP 4 & 35.39 \\
USP 1 vs. USP 4 & $\mathrm{P}$ & Low & 34.08 \\
& & High & 46.97 \\
USP 2 vs. USP 4 & $\mathrm{R}$ & Low & 61.57 \\
& & High & 24.75 \\
\hline
\end{tabular}

Table 5: Criteria used for the selection of the best fit model, mean, $n=12$

\begin{tabular}{|c|c|c|c|c|c|c|c|}
\hline Drug/dose & Higuchi & Korsmeyer-Peppas & Hixson-Crowell & Makoid-Banakar & Weibull & Logistic & Gompertz \\
\hline \multicolumn{8}{|c|}{ USP vessels apparatus } \\
\hline \multicolumn{8}{|c|}{$\mathrm{R}^{2}$ adjusted } \\
\hline $\mathrm{P} /$ low & 0.8344 & 0.9905 & 0.9065 & 0.9915 & 0.9877 & 0.8475 & 0.7802 \\
\hline P/High & 0.7556 & 0.9862 & 0.9063 & 0.9896 & 0.9784 & 0.9123 & 0.8534 \\
\hline R/low & 0.9078 & 0.9093 & 0.9659 & 0.9938 & 0.9974 & 0.9473 & 0.9074 \\
\hline R/High & 0.6297 & 0.7972 & 0.9688 & 0.9584 & 0.9975 & 0.9542 & 0.9423 \\
\hline \multicolumn{8}{|l|}{ AIC } \\
\hline $\mathrm{P} /$ low & 42.57 & 25.16 & 38.99 & 22.57 & 25.93 & 42.57 & 44.85 \\
\hline P/High & 43.39 & 25.13 & 37.14 & 22.12 & 27.18 & 37.67 & 40.91 \\
\hline R/low & 60.11 & 60.51 & 49.64 & 34.26 & 26.87 & 55.44 & 60.91 \\
\hline R/high & 67.35 & 62.79 & 44.11 & 48.54 & 20.14 & 47.79 & 50.43 \\
\hline \multicolumn{8}{|c|}{ Flow-through cell method } \\
\hline \multicolumn{8}{|c|}{$\mathrm{R}^{2}$ adjusted } \\
\hline $\mathrm{P} /$ low & 0.7692 & 0.9963 & 0.9459 & 0.9966 & 0.9968 & 0.9756 & 0.9436 \\
\hline P/High & 0.6859 & 0.9954 & 0.8889 & 0.9968 & 0.9886 & 0.9608 & 0.9218 \\
\hline R/low & 0.8255 & 0.8314 & 0.9153 & 0.9899 & 0.9981 & 0.9681 & 0.9485 \\
\hline R/High & 0.8565 & 0.8695 & 0.9286 & 0.9969 & 0.9994 & 0.9725 & 0.9808 \\
\hline \multicolumn{8}{|l|}{ AIC } \\
\hline P/low & 41.70 & 16.95 & 32.58 & 16.66 & 14.93 & 28.26 & 33.68 \\
\hline P/High & 43.53 & 17.46 & 36.89 & 16.23 & 21.24 & 30.98 & 35.58 \\
\hline R/low & 68.56 & 68.95 & 61.93 & 43.16 & 28.21 & 53.05 & 57.91 \\
\hline R/High & 62.39 & 61.31 & 54.77 & 27.06 & 12.13 & 46.07 & 43.74 \\
\hline
\end{tabular}

Only dissolution profiles of two doses of propranolol-HCl with flowthrough cell method and dissolution profiles of low dose of ranitidine$\mathrm{HCl}$, obtained with USP paddle apparatus and flow-through cell method, were similar $\left(f_{2}=50-100\right)$. Although USP Apparatuses 2 and 4 have different characteristics (especially hydrodynamic condition) it should be noted that dissolution profiles of low dose of ranitidine-HCl are similar. Results suggest that dissolution performance of low dose of ranitidine- $\mathrm{HCl}$ is independent of the hydrodynamic environment to which tablets were subjected.

Values of model-independent parameters: percentage of drug dissolved at last sampling time, MDT and DE of all formulations, are shown in table 3. Significant differences in all comparisons (Low vs. High dose) were found $\left({ }^{*} \mathrm{P}<0.05\right)$ excepting percentage of ranitidine$\mathrm{HCl}$ dissolved at $45 \mathrm{~min}$ with USP paddle apparatus as well as the percentage of propranolol- $\mathrm{HCl}$ dissolved at $30 \mathrm{~min}$ and MDT of ranitidine-HCl with flow-through cell method.

\section{Model-dependent comparisons}

The $t_{50 \%}, t_{63.2 \%}$, and $t_{85 \%}$ values derived from the adjustment to hyperbole model are shown in table 3 . Significant differences in all dissolution profiles of low vs. high dose, of both drugs, were found $\left({ }^{*} \mathrm{P}<0.05\right)$. Dissolution data of USP basket or paddle apparatus $v s$. 
flow-through cell were also compared and only dissolution profiles of low dose of ranitidine-HCl were similar $\left({ }^{*} \mathrm{P}>0.05\right)$ which corroborates the independence of low dose of this drug of the hydrodynamic environment surrounding the tablets.

Values of $\mathrm{R}^{2}$ adjusted and AIC obtained after the adjustment of dissolution data to all mathematical equations described above are shown in table 5. Considering the established criteria to choose the best fit model (highest $\mathrm{R}^{2}$ adjusted and lowest AIC) with USP vessels apparatus dissolution profiles of both doses of propranolol-HCl adjusted to Makoid-Banakar model and both doses of ranitidine-HCl adjusted to Weibull function. With the flow-through cell method both doses of ranitidine- $\mathrm{HCl}$ adjusted to Weibull model. Apparently, dissolution performance of both doses of ranitidine-HCl from the reference product can be explained with the same mathematical equation regardless of the dissolution system used.

To compare dissolution profiles of propranolol- $\mathrm{HCl}$ and ranitidine$\mathrm{HCl}$ with the previous settings $\mathrm{t}_{50 \%}, \mathrm{t}_{75 \%}$, and $\mathrm{t}_{80 \%}$ of propranolol- $\mathrm{HCl}$ (with USP basket apparatus data) were calculated and compared. Results are shown in table 6. Moreover, Weibull parameters of ranitidine- $\mathrm{HCl}$ (with both USP apparatuses data) were used to calculate the model-dependent parameter $T d$. Results are shown in table 7.

Table 6: Time parameters after adjustment of propranolol-HCl data to Makoid-Banakar model, mean $\pm \mathrm{SEM}, n=12 . * \mathrm{P}<0.05$, low $v s$. high dose

\begin{tabular}{llll}
\hline Dose & $\mathbf{t}_{\mathbf{5 0} \%}(\mathbf{m i n})$ & $\mathbf{t}_{\mathbf{7 5} \%} \mathbf{( m i n )}$ & $\left.\mathbf{t}_{\mathbf{8 0}} \mathbf{( m i n}\right)$ \\
\hline USP basket apparatus & & \\
Low & $13.15 \pm 0.26$ & $20.48 \pm 0.35$ & $21.91 \pm 0.36$ \\
High & $18.39 \pm 0.37^{*}$ & $25.88 \pm 0.45^{*}$ & $27.26 \pm 0.47^{*}$ \\
\hline
\end{tabular}

Table 7: Parameters after adjustment of ranitidine-HCl data to Weibull function. Mean, $n=12 .{ }^{*} \mathrm{P}<0.05$, low $v s$. high dose

\begin{tabular}{|c|c|c|c|c|c|}
\hline Dose & $\alpha$ & $\boldsymbol{\beta}$ & Ti & $F_{\max }$ & $\operatorname{Td}( \pm$ SEM) \\
\hline \multicolumn{6}{|c|}{ USP paddle apparatus } \\
\hline Low & 1980.87 & 1.78 & -3.03 & 105.72 & $15.34 \pm 0.56$ \\
\hline High & 7.81 & 0.94 & 2.14 & 105.24 & $8.53 \pm 0.16^{*}$ \\
\hline \multicolumn{6}{|c|}{ Flow-through cell method } \\
\hline Low & 155557.80 & 3.54 & -8.57 & 101.65 & $15.86 \pm 0.32$ \\
\hline High & 598.82 & 2.14 & -1.69 & 77.83 & $16.04 \pm 0.19$ \\
\hline
\end{tabular}

Significant differences were found with $t_{50 \%}, t_{75 \%}$, and $t_{80 \%}$ data of propranolol- $\mathrm{HCl}\left({ }^{*} \mathrm{P}<0.05\right)$ meaning that dissolution profiles of low and high dose of propranolol-HCl, obtained with USP basket apparatus, were not similar while significant differences in $T d$ values of ranitidine-HCl were found only with data obtained with USP paddle apparatus $\left({ }^{*} \mathrm{P}<0.05\right)$. Dissolution profiles of ranitidine- $\mathrm{HCl}$, obtained with USP paddle apparatus and flow-through cell method, were also compared and similar profiles were found only with the low dose.

In this in vitro release study of low and high dose, data fitting to models previously described were carried out without any physiological significance in order to find a mathematical equation that explains the in vitro dissolution performance of propranolol-HCl and ranitidine- $\mathrm{HCl}$ from Mexican reference products. The purpose of using mathematical models to adjust dissolution data is that they facilitate the analysis and interpretation of observed results because they describe the dissolution profiles as a function of only a few parameters that can be statistically compared [30].

Form a scientific point of view propranolol- $\mathrm{HCl}$ is a candidate for granting a biowaiver when the immediate-release tablets are formulated with well-known excipients, show rapid in vitro dissolution, and meet the dissolution profile comparison criteria as defined in the Guidances $\left(f_{2}=50-100\right.$ in dissolution media with $\mathrm{pH}$ of physiological relevance). The USP criteria and method are suitable to assure batch to batch consistency [6]. On the other hand, it would be reasonably safe to grant biowaivers for ranitidine- $\mathrm{HCl}$ immediaterelease solid oral dosage forms, provided that the test product is formulated with some excipients, in amounts typically used in this kind of formulations, and the test product is also rapidly dissolving [7]. In this sense, the drug products used are commercial products of which the type of excipients and the manufacturing process are unknow, but for their safety and efficacy previously proven, they have been chosen by the Mexican Health Authorities as reference drug products to be used in bioequivalence studies. These products are also used for in vitro dissolution studies of generic formulations.

The BCS suggests that for class I drugs and in some instances for class III drugs, $85 \%$ dissolution in $0.1 \mathrm{~N} \mathrm{HCl}$ in $15 \mathrm{~min}$ can ensure that the bioavailability of the drug is not limited by dissolution. In these cases, the rate limiting step for drug absorption is gastric emptying [31]. Of all dissolution profiles obtained in this in vitro dissolution study, only high dose of ranitidine-HCl with USP paddle apparatus met this dissolution criterion. The mean $t_{50 \%}$ gastric residence (emptying) time is $15-20$ min under fasting conditions. Based on this information, a conservative conclusion is that a drug product undergoing 85\% dissolution in $15 \mathrm{~min}$ under mild dissolution test conditions in $0.1 \mathrm{~N} \mathrm{HCl}$ behaves like a solution and generally should not have any bioavailability problems. If the dissolution is slower than gastric emptying, a dissolution profile with multiple points in multimedia is recommended [31]. On the other hand, for submission of a biowaiver request, an immediaterelease product (test and reference) should be rapidly dissolving (BSC class I) or very rapidly dissolving (BCS class III) [8]. Under pharmacopeial dissolution conditions used low dose of ranitidine$\mathrm{HCl}$ and all formulations with flow-through cell method do not comply with the requirement requested in the Guidance.

This is the first in vitro dissolution study with reference tablets of propranolol- $\mathrm{HCl}$ and ranitidine- $\mathrm{HCl}$ using USP vessels apparatus and flow-through cell method since comparative dissolution profiles with two doses of reference products are scarce. This work reveals significant differences in dissolution rate and extent of two doses of each drug used. On the other hand, comparative dissolution studies between USP paddle apparatus and flow-through cell method have been reported with ibuprofen and carbamazepine generic suspensions $[32,33]$ with the aim of improving these dosage forms. Hydrodynamics of USP Apparatus 4 best simulates human gastrointestinal tract. Shah et al. [34] stated that in order to increase the ability to detect any changes in the manufacturing process, a dissolution test at a lower agitation rate is preferred. Attentions should be given to the conditions to which the ingested solid dosage forms may be exposed in the stomach.

As dissolution data obtained with the flow-through cell method have been proved to better correlate with in vivo data $[28,35]$ and some pharmacopeial dissolution tests (that generally use USP vessels apparatus) do not allow to differentiate the rate and extent of in vitro release from generic drug products $[36,37]$ it is necessary to investigate new dissolution conditions that reflect the quality of generic formulations and estimate the in vivo performance of drugs. The quality of generic formulations depends on the available information of the dissolution performance of reference drug 
products under different conditions (e. g. hydrodynamics or $\mathrm{pH}$ medium). From a quality assurance point of view, a more discriminative dissolution method is preferred, because the test will indicate possible changes in the quality of the product before in vivo performance is affected [31].

For multiple strengths of immediate-release products with linear kinetics, the bioequivalence study may be performed at the highest strength and waivers of in vivo studies may be granted on lower strengths, based on an adequate dissolution test, provided the lower strengths are proportionately similar in composition [31]. This assertion may not be an absolute rule especially if significant differences in dissolution performance of two doses of drugs with high solubility (class I or III) are documented. The search of "adequate dissolution test" must be essential for to ensure quality, safety and efficacy of drug products of any country. Some authors have reported that the effect of propranolol on portal pressure in patients with portal hypertension is highly variable and does not correlate with propranolol racemate or stereoisomer plasma concentrations [38]. Differences on in vitro behavior found in this work could explain in vivo performance of propranolol.

It is important to consider bioequivalence data of the drugs used in this work. Polli [39] reported the association of dissolution rate of three ranitidine-HCl tablets and their bioequivalences relative to the reference product. He found all formulations bioequivalent despite differences in dissolution rates. The author asserts that differences in dissolution rates observed earlier than $30 \mathrm{~min}$ had negligible consequences in vivo. It is necessary to carry on IVIVC studies with both doses of propranolol- $\mathrm{HCl}$ and ranitidine- $\mathrm{HCl}$ to evaluate the predictability of the proposed methodology since if problems are reported with reference drug products the quality of generic formulations will be affected.

\section{CONCLUSION}

In vitro dissolution performance of two doses of propranolol-HCl and ranitidine- $\mathrm{HCl}$ under the hydrodynamic environment of USP basket or paddle apparatus and the flow-through cell was not expected. It is essential to carry out bioequivalence studies with the lowest and highest doses of reference products used. This action seems not to be necessary for class I and III drugs, however, due to the results obtained in the present work it must be confirmed that significant differences in dissolution profiles do not affect the bioequivalence of both doses. More research on in vitro dissolution performance of all available doses of reference products is necessary.

\section{AUTHORS CONTRIBUTIONS}

All the author have contributed equally

\section{CONFLICT OF INTERESTS}

\section{Declared none}

\section{REFERENCES}

1. Ashrafi S, Shapouri R, Shirkhani A, Mahdavi M. Anti-tumor effects of propranolol: adjuvant activity on a transplanted murine breast cancer model. Biomed Pharmacother 2018;104:45-51.

2. Porwal A, Swami G, Saraf SA. Preparation and evaluation of sustained release micro-balloons of propranolol. DARU 2011;19:193-201.

3. Maharjan R, Subedi G. Formulation and evaluation of floating in situ gel of ranitidine using natural polymers. Int J Pharm Pharm Sci 2014;6:205-9.

4. World Health Organization. Model List of Essential Medicines; 2017. Available from: https://apps.who.int/iris/bitstream/ handle/10665/273826/EML-20-eng.pdf?ua=1. [Last accessed on 30 Mar 2019].

5. Lindenberg M, Kopp S, Dressman JB. Classification of orally administered drugs on the World Health Organization model list of essential medicines according to the biopharmaceutics classification system. Eur J Pharm Biopharm 2004;58:265 -78.

6. Vogelpoel H, Welink J, Amidon GL, Junginger HE, Midha KK, Möller $\mathrm{H}$, et al. Biowaiver monographs for immediate release solid oral dosaje forms based on a biopharmaceutics classification system (BCS) literatura data: verapamil hydrochloride, propranolol hydrochloride, and atenolol. J Pharm Sci 2004;93:1945-56.

7. Kortejarvi H, Yliperttula M, Dressman JB, Junginger HE, Midha $\mathrm{KK}$, Shah VP, et al. Biowaiver monographs for immediate release solid oral dosage forms: ranitidine hydrochloride. J Pharm Sci 2005;94:1617-25.

8. Food and Drug Administration. Guidance for Industry: Waiver on in vivo bioavailability and bioequivalence studies for immediate-release solid oral dosage forms based on a biopharmaceutics classification system; 2017. Available from: https://www.fda.gov/downloads/Drugs/./Guidances/UCM070 246.pdf. [Last accessed on 30 Mar 2019].

9. United States Pharmacopeia and National Formulary USP 41NF 36; The United States Pharmacopeial Convention, Inc: Rockville MD; 2018.

10. Farmacopea de los Estados Unidos Mexicanos. 11a. ed. México DF, Secretaría de Salud; 2014.

11. Sunesen VH, Pedersen BL, Kristensen HG, Müllertz A. In vitro in vivo correlations for a poorly soluble drug, danazol, using the flow-through dissolution method with biorelevant dissolution media. Eur J Pharm Sci 2005;24:305-13.

12. Szymanska E, Winnicka K. Comparison of flow-through cell and paddle methods for testing vaginal tablets containing a poorly water-soluble drug. Trop J Pharm Res 2013;12:39-44.

13. Emara LH, Emam MF, Taa NF, El-Ashmawy AA, Mursi NM. In vitro dissolution study of meloxicam immediate release products using flow-through cell (USP Apparatus 4) under different operational conditions. Int J Pharm Pharm Sci 2014;6:254 -60.

14. Jinno J, Kamada N, Miyake M, Yamada K, Mukai T, Odomi M, et al. In vitro-in vivo correlation for the wet-milled tablet of poorly water-soluble cilostazol. J Controlled Release 2008;130:29-37.

15. Jantratid E, De Maio V, Ronda E, Mattavelli V, Vertzoni M, Dressman JB. Application of biorelevant dissolution tests to the prediction of in vivo performance of diclofenac sodium from an oral modified-release pellet dosage form. Eur J Pharm Sci 2009;37:434-41.

16. Medina JR, Ortiz HD, Hurtado M, Dominguez Ramirez AM. Influence of dose and the USP basket and flow-through cell dissolution apparatuses in the release kinetics of metronidazole immediaterelease products. Int J Res Pharm Sci 2014;5:137-46.

17. Rediguieri CF, Porta V, Nunes DSG, Nunes TM, Junginger HE, Kopp S, et al. Biowaiver monographs for immediate release solid oral dosage forms: metronidazole. J Pharm Sci 2011;100:1618-27.

18. Daousani C, Macheras P. Scientific considerations concerning the EMA change in the definition of "dose" of the BCS-based biowaiver guideline and implications for bioequivalence. Int J Pharm 2015;478:606-9.

19. COFEPRIS. Listado actualizado de medicamentos de referencia 2017/08, Mexico. Available from: https://www.gob.mx/ cms/uploads/attachment/file/197452/IMR_201708_V006.pdf. [Last accessed on 30 Mar 2019]

20. Moore JW, Flanner HH. Mathematical comparison of dissolution profiles. Pharm Technol 1996;20:64-75.

21. Podczeck F. Comparison of in vitro dissolution profiles by calculating mean dissolution time (MDT) or mean residence time (MRT). Int J Pharm 1993;97:93-100.

22. Anderson NH, Bauer M, Boussac N, Khan-Malek R, Munden P, Sardaro M. An evaluation of fit factors and dissolution efficiency for the comparison of in vitro dissolution profiles. J Pharm Biomed Anal 1998;17:811-22.

23. Demirturk E, Oner L. In vitro-in vivo correlations. FABAD J Pharm Sci 2003;28:215-24.

24. Zhang Y, Huo M, Zhou J, Zou A, Li W, Yao C, et al. DD Solver: an add-in program for modeling and comparison of dissolution profiles. AAPS J 2010;12:263-71.

25. Yuksel N, Kanik AE, Baykara T. Comparison of in vitro dissolution profiles by ANOVA-based, model-dependent and independent methods. Int J Pharm 2000;209:57-67.

26. Kortejarvi H, Shawahna R, Koski A, Malkki J, Ojala K, Yliperttula M. Very rapid dissolution is not needed to guarantee bioequivalence for biopharmaceutics classification system (BCS) I drugs. J Pharm Sci 2010;99:621-5. 
27. Shokhin IE, Ramenskaya GV, Vasilenko GF, Malalshenko EA. Assessment of the possibility of using comparative in vitro dissolution kinetics (biowaiver) instead of in vivo bioequivalence evaluation for establishing the interchangeability of generic drugs. Pharm Chem J 2011;45:107-9.

28. Langenbucher F, Benz D, Kurth W, Moller H, Otz M. Standardized flow-cell method as an alternative to existing pharmacopoeial dissolution testing. Pharm Ind 1989;51:1276 -81.

29. Steffansen B, Brodin B, Und Nielsen C. editors. Molecular Biopharmaceutics. ULLA Pharmacy Series. Pharmaceutical Press; 2010.

30. Adams E, Coomans D, Smeyers Verbeke J, Massart DL. Nonlinear mixed effects models for the evaluation of dissolution profiles. Int J Pharm 2002;240:37 -53.

31. Food and Drug Administration. Guidance for Industry: Dissolution testing of immediate release solid dosage forms; $1997 . \quad$ Available from: https://www.fda.gov/downloads/drugs/guidances/ucm07023 7.pdf. [Last accessed on 30 Mar 2019]

32. Medina JR, Cortes M, Romo E. Comparison of the USP apparatus 2 and 4 for testing the in vitro release performance of ibuprofen generic suspensions. Int J Appl Pharm 2017;9:90-5.

33. Medina JR, Aguilar E, Hurtado M. Dissolution behavior of carbamazepine suspensions using the USP dissolution apparatus 2 and the flow-through cell method with simulated GI fluids. Int J Pharm Pharm Sci 2017;9:111 -6.

34. Shah VP, Gurbarg M, Noory A, Dighe S, Skelly JP. Influence of high rates of agitation on release patters of immediate-release drug products. J Pharm Sci 1992;81:500 -3.

35. Emara LH, El-Menshawi BS, Estefan MY. In vitro-in vivo correlation and comparative bioavailability of vicamine in prolonged-release preparations. Drug Dev Ind Pharm 2000;26:243-51.

36. Hurtado M, Vargas Y, Dominguez Ramirez AM, Cortes AR. Comparison of dissolution profiles for albendazole tablets using USP apparatus 2 and 4. Drug Dev Ind Pharm 2003;29:777-84.

37. Medina JR, Salazar DK, Hurtado M, Cortes AR, Dominguez Ramirez AM. Comparative in vitro dissolution study of carbamazepine immediate-release products using the USP paddles method and the flow-through cell system. Saudi Pharm J 2014;22:141-7.

38. Cales P. Optimal use of propranolol in portal hypertension. Gastroenterol Clin Biol 2005;29:207-8.

39. Polli JE. In vitro-in vivo relationships of several "immediate" release tablets containing a low permeability drug. In: Young D, Devane JG, Butler J. editors. In vitro-in vivo correlations. 1st ed. Boston: Springer; 1997. p. 191-8. 